\title{
Socio-economic factors influencing household forest dependency in Chobe enclave, Botswana
}

\author{
Hesekia Garekae ${ }^{1 *} \mathbb{D}$, Olekae Tsompie Thakadu² (D) and Joyce Lepetu ${ }^{3}$
}

\begin{abstract}
Introduction: Human dependence on forests is a multifaceted phenomenon. The degree of reliance on forests varies geographically, overtime and across communities. These dynamics underpin the importance of understanding the determinants of household reliance on forests for the long-term sustainable forest management and conservation. This paper presents an analysis of socio-economic determinants on the level of household forest dependency in Chobe enclave, Botswana. The study hypothesised that the level of household forest dependency will significantly differ across a range of socio-economic factors.

Methods: Data was collected through a structured questionnaire survey of 183 households, randomly selected from three communities bordering Chobe Forest Reserve. Binary logistic regression model was used for analysing data.

Results: Results showed that age and education significantly influenced household reliance on forests, while other socio-economic factors were not significant. Forest dependency was observed to be decreasing with an increase on both respondent age and educational level. Therefore, the youth were likely to be more reliant on forest products compared to their elderly counterpart while higher educational attainment lessened reliance on forest products.

Conclusion: In order to foster a balance between forest dependency and biodiversity conservation, alternative opportunities and provision and access to higher education aimed at diversifying young people's livelihood activities are vital in reducing forest dependency, hence protecting forests for posterity.
\end{abstract}

Keywords: Forest dependency, Biodiversity conservation, Rural-urban migration, Chobe Forest Reserve, Botswana

\section{Introduction}

Since time immemorial, forests and their associated products have remained essential in sustaining livelihoods (Mamo et al. 2007; Bwalya 2013; Mukul et al. 2016), particularly for the people of forest-dependent communities, who live in abject poverty (Shackleton et al. 2007; Kabubo-Mariara 2013). About 1.6 billion people globally are substantially reliant on forests for livelihood sustenance (World Bank 2002). Numerous studies on forest-livelihood nexus have demonstrated the critical role of forests in livelihood sustenance and

\footnotetext{
* Correspondence: garekae@yahoo.com

${ }^{1}$ Department of Environmental Science, Rhodes University, P.O. Box 94,

Grahamstown, South Africa

Full list of author information is available at the end of the article
}

diversification and as a pathway for poverty alleviation (Mamo et al. 2007; Vedeld et al. 2007; Uberhuaga et al. 2012; Mukul et al. 2016). Forests are essential in provision of basic needs, cash savings and safety nets (Shackleton et al. 2007). They are a source of energy, employment, medicine and other subsistence needs for the majority of local communities, especially in developing countries (Bahuguna 2000).

Globally, empirical evidence has quantified and qualified the proportion of forest dependency from the entire household livelihood matrix. The seminal work by Vedeld et al. (2007) drawing upon 51 case studies across 17 developing countries revealed that the contribution of forests, mainly through forest income accounted for about $22 \%$ of the total household income. In North and 
South America, the contribution of forest income ranged between 14 and $20 \%$ of the total household income (Uberhuaga et al. 2012; Córdova et al. 2013). In Asia, forest income varied from 10 to $20 \%$ of the total household income (Mukul et al. 2016). While in sub-Saharan Africa, forest income ranged from 30 to $45 \%$ of the total household income (Mamo et al. 2007; Appiah et al. 2009; Kalaba et al. 2013). These studies demonstrated the significant contribution of forests towards household economies. Some people depend solely on forests as their only source of subsistence, with its contribution sometimes being found to offset other household livelihood portfolios such as agriculture (McElwee 2010).

Despite the contribution of forests on livelihoods, human dependence on forests is a multifaceted phenomenon (Beckley 1998). The level of use and degree of reliance on forests and its importance as a source of subsistence varies geographically, over time and across communities (Babulo et al. 2008; Bwalya 2013). Since communities are not homogenous in nature, variation on household reliance on forests is inevitable (Coomes et al. 2004; Córdova et al. 2013). Drawing upon the forest dependency literature, reliance on forest is a function of various factors and key among them includes a household's socio-economic factors (Obua et al. 1998; Panta et al. 2009; Bhavannarayana et al. 2012). For example, higher education attainment is associated with less reliance on forest resources (Panta et al. 2009; Fonta and Ayuk 2013). This is so because education offers other alternative livelihood opportunities which may generate significant returns compared to forest extraction activities (Masozera and Alavalapati 2004). Household size is positively associated with forest dependency. Larger families have higher subsistence needs which necessitate them to depend more on forest resources (Gunatilake 1998; Mamo et al. 2007). On the other hand, age of household head is positively related with forest dependency, albeit with diminishing effect after reaching a peak of physical strength (Godoy et al. 1997). However, older people might possess strong ecological knowledge about their proximate environment, a phenomenon which might increase their likelihood of being more dependent on forest resources.

The above dynamics underpin the importance of understanding the determinants of household reliance on forests for the long-term sustainable forest management and conservation (Gunatilake 1998; Hegde and Enters 2000). This is a fundamental step towards designing target-specific interventions to reducing forest dependency, planning, policy development and sustainable management strategies (Babulo et al. 2008; Dagm et al. 2016). An understanding of the level of utilisation and pattern of forest dependency will enable researchers, policy makers and practitioners to design empirically informed interventions to diversify households' livelihood portfolios and promote sustainable resource utilisation in order to foster a balance between forest dependency and biodiversity conservation (Baiyegunhi et al. 2016; Dagm et al. 2016). Against this backdrop, this study aimed at analysing the socio-economic determinants on the level of household's forest dependency in Chobe enclave, Botswana. In order to achieve this, the following research questions were posed to guide the study: (1) what is the level of household forest dependency? (2) How do socio-economic factors influence household forest dependency? Following, we hypothesised that the level of household forest dependency will significantly differ across a range of socio-economic factors.

\section{Methods}

\section{Study area}

The study was undertaken in the Chobe enclave within the Chobe district, northern Botswana (Fig. 1). Chobe district covers an area of $22,052 \mathrm{~km}^{2}$, and about $70 \%$ of this land is gazetted protected areas: national park, forest reserves and wildlife management areas. The district is located within the lines of longitude $24^{\circ} 00-26^{\circ} 00 \mathrm{E}$ and between latitude $17^{\circ} 0045^{\prime}$ and $19^{\circ} 00 \mathrm{~S}$ (see Fig. 1). Chobe district is a quadripoint to Botswana, Zimbabwe, Zambia and Namibia. The district is categorised into two distinct groups: eastern cluster community (Kazungula, Lesoma and Pandamatenga) and western cluster community (Mabele, Kavimba, Kachikau, Satau and Parakarungu). Kasane township which demarcates the two clusters serves as the district administrative centre, housing various government departments, luxurious accommodation facilities (five star hotels and lodges) and retail-chain stores.

The study focus was on the western cluster community, commonly known as Chobe enclave. The enclave comprises a line of five villages spanning along the Chobe River basin (Fig. 1). Chobe enclave boasts with the countries pristine flora, fauna and aquatics such as the diverse wildlife population (hosted at Chobe National Park), trans-boundary water bodies (Chobe River) and dense miombo woodlands thicket (Chobe Forest Reserve). This various resources endowed in the enclave are integral to communities' livelihoods. The Chobe Forest Reserve (CFR) provides the adjacent communities with nontimber forest products (NTFPs) which are critical for provision of household energy, building materials, medicine and agricultural inputs. Chobe River is essential in ensuring food security through availability of varied fish species, edible plants and flood recession farming.

Three villages, Mabele, Kavimba and Kachikau were purposively sampled from the entire Chobe enclave community (see Fig. 1). The villages were mainly chosen based on their proximity to CFR, which is an integral component to their livelihood sustenance. The three villages are contiguous with CFR to the west, with Kachikau 


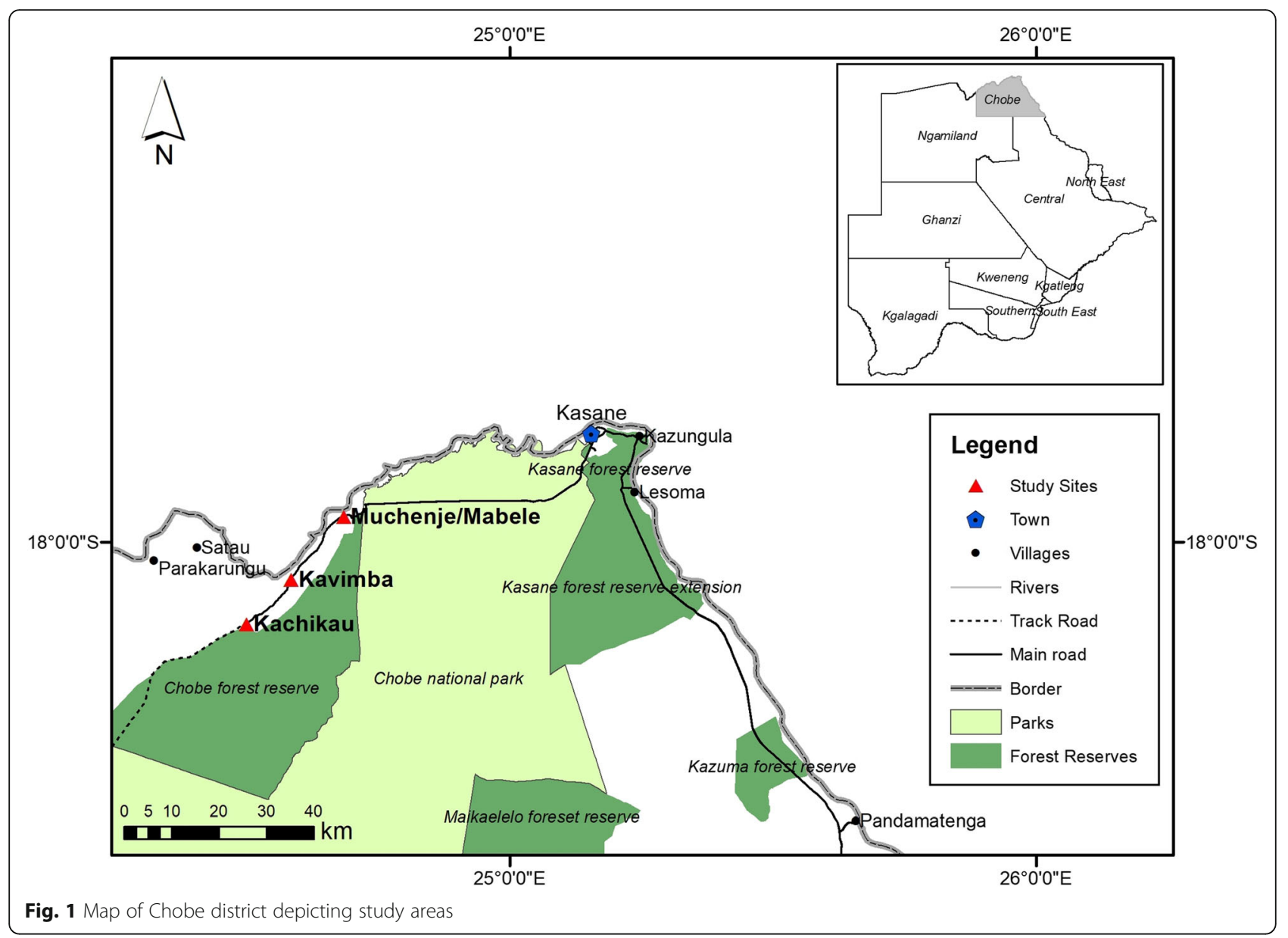

being the closet settlement to the reserve, followed by Kavimba and Mabele. The villages consist of 2678 inhabitants (Statistics Botswana 2011b) of diverse ethnic backgrounds. Chobe enclave is multi-ethnic, with the BaSubiya constituting the majority across the study areas while BaTawana, BaMbukushu and BaYeyi were few. The study villages have diversified economic activities, mainly in three domains: crop production, livestock production and wage employment. Moreover, crop production is favoured by the high rainfall and fertile soils endowed in Chobe enclave. Also, the perennial Chobe River accords the arable farmers the opportunity to practise dual planting tenure system: rain fed (dry land) and flood recession farming. This farming system is very critical during times of shocks as the output production of one complements the other. On the other hand, the primary livelihood activities were supplemented by activities such as fishing, traditional beer brewing, NTFPs harvesting, weaving and crafting.

\section{Design and sampling}

The study participants were drawn from the villages of Mabele, Kavimba and Kachikau. The sampled villages consist of about 536 households. Simple random sampling technique was used to draw a sample size of 183 households to form part of the study survey, representing approximately $34 \%$ of the entire households in the study villages. The sampling procedure followed this order: a list of all the households residing in each respective study village was compiled to design a sampling framework, and then, each household within the sampling framework was assigned a number consecutively (Babbie 2016). A computer generated randomised table number was used to sample the required number of households from the entire sampling framework. The unit of analysis was the household head, and in exceptional circumstances, any household member who was 18 years and above was considered in lieu of the household head.

\section{Data collection}

The study draws from the responses of the survey questionnaire which was administered to the respondents in the three study villages. A standardised semi-structured questionnaire was administered to the respondents through face to face interviews, conducted by the 
researchers at the interviewees' homes and at agreed convenient times. Firstly, the study purpose and objectives were fully explained to the respondents. All ethical procedures were followed.

\section{Development of the instrument}

The survey questionnaire was written in English (official) and Setswana (national) languages; a language teacher examined the duo instruments for consistency and accuracy. The questionnaire composed of two main sections. Section 1 contained questions covering respondent's demographic and socio-economic background. This included sex, age, ethnicity, education level, employment, household income, length of residency, household size, type and total number of livestock head, and crops grown and their equivalent output. Below is the description of how the latter variables were operationalised in this study.

Sex: it was measured as a dummy variable to assign respondents into two gender groups: male and female.

Age: denotes the actual number of years lived by the household head.

Ethnicity: describes the social groupings individual household identify to, with communal believes, language and culture.

Education level: depicts the highest qualification attained by the household head. In this study, education level was categorised into four groups: primary (7 year education level), secondary (12 year education level) and tertiary (post-secondary education).

Employment status: denotes the state of whether or not an individual household head engages in remunerated work. The variable was categorised into four groups: fulltime, part-time, self-employed and unemployed.

Household income: represents the sum of monies accruing to all people in a given household; this includes income from wage and salaried jobs and other sources such as business, remittances and social grants. However, due to the sensitivity of the variable to most respondents, it was recorded as a categorical data (see Table 2) in order to easy the respondents to reveal their monthly income expenditures. Consequently, this limited the ability of the variable to form part of the logit model predictors, hence its omission from the analysis.

Length of residency: denotes the number of years a household resided in the respective study area.

Household size: denotes the total number of people living within a given household unit. Livestock: depicts rearing of livestock for subsistence and to a lesser extent commercial purposes. Livestock records were solicited from individual households, which included the type (e.g. cattle, goat, sheep) and equivalent number of each livestock head. During preliminary data analysis, the variable was transformed into monetary value. Prices for each type of livestock were obtained from the local market.

Crop production: depicts the cultivation of crops for subsistence purposes and to a lesser extent commercial. Data on each type of crop (e.g. sorghum, maize, millet) cultivated and equivalent yields were recorded from each household. During preliminary data analysis, the variable was transformed into monetary value. Prices of crops were sourced from Botswana Agricultural Marketing Board (BAMB), a national agency mandated with providing market for locally grown crops. Some households reported to be selling their crop surpluses to BAMB.

On the other hand, section 2 of the questionnaire contained questions focussing on resources collected from CFR for household utilisation. Data on the various types of forest products, frequency and quantity of collection and level of reliance on forest resources were solicited from the respondents. The method of formulating questionnaire was guided by literature review (Masozera and Alavalapati 2004; Fonta and Ayuk 2013; Jain and Sajjad 2015).

\section{Data analysis}

Data was compiled and managed using Statistical Package for Social Sciences (SPSS) version 24. Descriptive statistics in the form of frequencies, proportions, measures of central tendency and dispersion were used to summarise the socio-demographic data. Logistic regression analysis was used to test for socio-economic factors predictive ability on forest dependency. In this study, the outcome variable (forest dependency) was regressed against selected explanatory variables: age, length of residency, household size, sex, education and employment. These variables were used as a proxy for socio-economic. The variables were chosen mainly because they cut across the social and economic domains; hence, they will provide a comprehensive insight on the pattern of household forest dependency. The outcome variable forest dependency was measured as a dichotomous response occupying the value of 1 or 0 , where 1 denotes high forest dependency while 0 means low forest dependency. Binary logistic regression model was used (Hosmer et al. 2013) to determine the socioeconomic factors influencing households' forest dependency. Since there is no set conventional cut-off point for classifying forest dependency, the average value across the study villages was considered as the threshold for categorising forest dependency into two levels: low and high. This approach has being widely used in forest dependency literature (see Jain and Sajjad 2015). Hence, the cut-off point value of 0.5 was used in this study. The forest dependency value of $\leq 0.5$ therefore denotes low dependency while a value of $\geq 0.5$ indicates high dependency. Below is the description of the model used to determine the socioeconomic factors influencing forest dependency: 


$$
\text { Logit }(Y)=\operatorname{In}\left(\frac{\pi}{1-\pi}\right)=\alpha+\beta_{1} X_{1}+\beta_{2} X_{2}
$$

Therefore,

$$
\begin{aligned}
\pi=\text { Probability }\left(Y=\text { outcome } \mid X_{1}\right. & \left.=x_{1}, X_{2}=x_{2}\right) \\
& =\frac{e^{\alpha+\beta_{1} X_{1}+\beta_{2} X_{2}}}{1+e^{\alpha+\beta_{1} X_{1}+\beta_{2} X_{2}}}
\end{aligned}
$$

where $\pi$ denotes the probability of an outcome, $\alpha$ is the $Y$ intercept, $\beta$ 's are the regression coefficients, $X$ 's are the set of explanatory variables, and $e=2.71828$ (natural logarithms base).

In this study, the variables age, length of residency, household size, sex, education and employment were used to explain households' forest dependency. Table 1 presents the description and measurement of the explanatory variables used in the logit model.

\section{Results}

\section{Household profiles}

Of the total sampled population, $61.2 \%(n=112)$ were females (Table 2). Most of the household heads were on their middle-age group $(M=49.33, \mathrm{SD}=17.28)$. More than one third of the household heads $(44.8 \%, n=82)$ had attained primary education as their highest education level, while only ten $(5.5 \%)$ indicated tertiary. However, $13.1 \%(n=24)$ indicated that they have not attained any formal education (Table 2). Chobe enclave and the rest of Chobe district have been hard hit by high unemployment rate, estimated at $19 \%$ of the entire district (Statistics Botswana 2011a). About 54\% $(n=99)$ of the household heads reported as being unemployed while only $12.6 \%$ $(n=23)$ were employed on full-time basis (Table 2). The average household size consisted of $4.85(\mathrm{SD}=2.64)$ persons with majority $(42.8 \%, n=77)$ of them reporting an

Table 1 The description of the explanatory variables used in the logit model

\begin{tabular}{|c|c|c|c|c|c|}
\hline Variable & Items & $N$ & $M(S D)$ & $\%$ & $n$ \\
\hline \multirow[t]{2}{*}{ Gender } & Male & & & 38.8 & 71 \\
\hline & Female & & & 61.2 & 112 \\
\hline Age (years) & & & $49.33(17.28)$ & & 182 \\
\hline \multirow[t]{7}{*}{ Ethnicity } & BaSubiya & & & 53 & 97 \\
\hline & BaYei & & & 13.7 & 25 \\
\hline & BaTawana & & & 10.9 & 20 \\
\hline & BaMbukushu & & & 6.6 & 12 \\
\hline & BaSarwa & & & 7.1 & 13 \\
\hline & BaNabjwa & & & 0.5 & 1 \\
\hline & Others & & & 8.2 & 15 \\
\hline \multirow[t]{4}{*}{ Education level } & None & & & 13.1 & 24 \\
\hline & Primary & & & 44.8 & 82 \\
\hline & Secondary & & & 36.1 & 66 \\
\hline & Tertiary & & & 5.5 & 10 \\
\hline \multirow[t]{5}{*}{ Employment status } & $\begin{array}{l}\text { Full-time } \\
\text { employed }\end{array}$ & & & 12.6 & 23 \\
\hline & $\begin{array}{l}\text { Part-time } \\
\text { employed }\end{array}$ & & & 6.6 & 12 \\
\hline & Self-employed & & & 14.2 & 26 \\
\hline & Unemployed & & & 54.1 & 99 \\
\hline & Others & & & 12.6 & 23 \\
\hline \multirow{7}{*}{$\begin{array}{l}\text { Average monthly } \\
\text { income (USD) }\end{array}$} & $<45.00$ & & & 42.8 & 77 \\
\hline & $>45.00<90.00$ & & & 32.2 & 58 \\
\hline & $>90.00<135.00$ & & & 7.8 & 14 \\
\hline & $>135.00<180.00$ & & & 3.9 & 7 \\
\hline & $>180.00<225.00$ & & & 6.1 & 11 \\
\hline & $>225.00<270.00$ & & & 3.3 & 6 \\
\hline & $>270.00$ & & & 3.9 & 7 \\
\hline Household size & & 183 & $4.85(2.64)$ & & \\
\hline $\begin{array}{l}\text { Length of residency } \\
\text { (years) }\end{array}$ & & & $40.26(20.73)$ & & 175 \\
\hline
\end{tabular}

\begin{tabular}{lll}
\hline Variables & Explanation & Expected sign \\
\hline Age & $\begin{array}{l}\text { Age of household head in years } \\
\text { Length of residency }\end{array}$ & $\begin{array}{l}\text { Positive } \\
\text { respective study area }\end{array}$ \\
Household size & $\begin{array}{l}\text { Number of family members in } \\
\text { the household }\end{array}$ & Positive \\
Sex & 1 if male, 0 if female & Positive \\
Education & $\begin{array}{l}\text { Household head level of } \\
\text { education }(0=\text { none, } 1=\end{array}$ & Negative \\
& $\begin{array}{l}\text { primary, } 2=\text { secondary, } \\
\text { 3 tertiary })\end{array}$ & \\
Employment & $\begin{array}{l}\text { Household head employment } \\
\text { status }(0=\text { unemployed, }\end{array}$ & Negative \\
& $1=$ others, $2=$ employed $)$ & \\
\hline
\end{tabular}

Table 2 Summary of households' profile

$N$ total sample size, $M$ mean, $S D$ standard deviation, $n$ subset of the sample

average monthly income of USD $45.00^{1}$ or less. Most of the household heads lived in their area of settlement since birth, as evidenced from the mean length of residency of $40.26(\mathrm{SD}=20.73)$ years. Table 2 provides a summary of household profiles.

\section{Household dependency on forests}

About $86.3 \%(n=158)$ of the households reported that they have visited CFR within the past 3 years (2014-2016). Almost all of the households $(99.4 \%, n=157)$ attributed their visitation to be solely on harvesting of forest products. Following, the perceived level of household's reliance on forests was assessed. The respondents were presented with statements which they were asked to agree or disagree and indicate the level of their agreement or disagreement, 
ranging from very low dependency (coded 1) to very high dependency (coded 5). With regard to the itemised statements, results indicate that about half of the households $(54.1 \%, n=85)$ were highly dependent on forest for their livelihoods, whereas about one fifth $(20.4 \%(n=32)$ and $5.1 \%(n=8))$ were moderately and least dependent respectively. Various forest products were collected from the nearby forest reserve; however, firewood $(85.8 \%, n=157)$ was the most collected by the respondents while fodder was the least $(2.7 \%, n=5$ ) (see Garekae (2016) for a detailed account on forest resources utilisation in the study areas).

The household perceived level of reliance on forest resources was further ascertained by the forest dependency index (FDI). The mean FDI was $0.50(\mathrm{SD}=0.41)$, suggesting that households were moderately dependent on forest resources. However, the FDI demonstrated that household reliance on forests varied with their area of settlement. Residents of Kachikau were relatively twice as dependent on forests compared to the ones in Mabele and Kavimba and had an index of 0.65 indicating high forest dependency. Mabele and Kavimba had an FDI of 0.34 and 0.30 respectively.

\section{Socio-economic factors influencing household dependence on forests}

Binary logistic regression model was run to assess the predictive ability of the selected socio-economic factors on household forest dependency. Preliminary analyses were conducted to test for multicollinearity, and no violations were observed. The maximum Mahalanobis distance was $X^{2}=19.80, p<.001$, and this is less than the set critical value of $\chi^{2}=22.46, p<.001$. All the explanatory variables were above the conventional cut-off point for tolerance and variance inflation factor (VIF): none of them had tolerance less than 0.10 and greater than 10 for VIF. The likelihood ratio test shows that the regression model is significant $\left(\chi^{2}=(9, n=150)=21.00\right.$, $p=.01)$. This finding indicates that a significant relationship exists between the explanatory variables and forest dependency (outcome variable). The model as a whole explained between 13.1\% (Cox and Snell $R^{2}$ ) and 17.4\% (Nagelkerke $R^{2}$ ) of the variance on forest dependency and correctly classified $66 \%$ of the cases.

As presented in Table 3, only two predictors: age and education made a statistically significant contribution towards predicting forest dependency. Since the coefficient of age was negative, the odds of reporting high forest dependency decreased with age $(\mathrm{OR}=0.96)$. This suggests that an increase on the age of household head results in decrease on forest dependency by a factor of 0.96, all other factors being equal. The finding implies that the youthful households were likely to gather more forest products compared to the middle aged and the elderly.
Table 3 Logistic regression model for factors influencing household forest dependency

\begin{tabular}{lllllll}
\hline Predictor & $B$ & SE & Wald & $\operatorname{Exp}(B)$ & \multicolumn{2}{c}{$95 \% \mathrm{Cl}$ for $\operatorname{Exp}(B)$} \\
\cline { 6 - 8 } & & & & & Lower & Upper \\
\hline Age & -0.04 & 0.02 & 5.96 & $0.96^{*}$ & 0.93 & 0.99 \\
Length of residency & 0.01 & 0.01 & 1.09 & 1.01 & 0.99 & 1.03 \\
Household size & -0.12 & 0.07 & 2.91 & 0.89 & 0.77 & 1.02 \\
Sex & -0.11 & 0.37 & 0.09 & 0.89 & 0.45 & 1.85 \\
Education (primary) & -0.83 & 0.60 & 1.89 & 0.44 & 0.13 & 1.42 \\
Education (secondary) & -1.89 & 0.72 & 6.79 & $0.15^{*}$ & 0.04 & 0.63 \\
Education (tertiary) & -2.18 & 1.05 & 4.28 & $0.11^{*}$ & 0.01 & 0.89 \\
Employment (other) & 0.45 & 0.45 & 0.97 & 1.56 & 0.64 & 3.79 \\
Employment (employed) & -0.23 & 0.47 & 0.23 & 0.80 & 0.32 & 2.02 \\
Constant & 3.22 & 1.21 & 7.09 & 24.92 & &
\end{tabular}

$B$ beta coefficients, SE stand error, $\operatorname{Exp}(B)$ odd ratio (OR) ${ }^{*} p<.05$

Similarly, the coefficients of education were negative and the odds of reporting high forest dependency decreased with transition from secondary $(\mathrm{OR}=0.15)$ to tertiary $(\mathrm{OR}=0.11)$ education levels respectively. The result suggests that household heads with higher educational levels were more likely to gather less forest products compared to those with lower levels or none. On the other hand, the variables length of residency, household size, sex and employment were not statistically significant but showed both positive and negative association with forest dependency. Table 3 presents the results of the forest dependency model.

\section{Discussion}

The study results revealed that households were generally highly dependent on forests for their livelihood sustenance. This high reliance on forest products is necessitated by the abject poverty $(20 \%$ (Statistics Botswana 2015b)) prevalent within the Chobe district. Also, the land use tenure systems in Chobe enclave aggravate the situation; the enclave is sandwiched between protected areas (Chobe National Park, Chobe Forest Reserve and Wildlife Management Areas). Despite Chobe enclave locals being primarily farmers, the dense wildlife population in the area compromise their efforts through frequent crop-raiding and preying on livestock. Hence, forest products and other natural resources in the area are paramount to household sustenance in Chobe enclave.

The findings demonstrated that household place of residency, age and education level statistically and significantly influenced forest dependency. With regard to place of residency, Kachikau residents were relatively twice more dependent on forests compared to the ones in Mabele and Kavimba. This observation is attributed 
to the distance of the study sites to the forest reserve: Kachikau village is very close to the reserve while the other two are slightly distal. Therefore, the time for collecting forest products is shortened for Kachikau residents, hence promoting sustained harvesting. This finding is consistent with other studies from elsewhere which established that proximity to the forests increases the likelihood of households to exhibit greater reliance on forest products compared to the furthest ones (Baiyegunhi et al. 2016; Dagm et al. 2016; Mukul et al. 2016).

Secondly, the findings revealed an inverse relationship between age of household head and forest dependency. The odd ratio for the coefficient of age implies that, for a year increase in the age of the household head, households were relatively one time less likely to be more reliant on forest resources. Hence, the youth were more likely to be reliant on forest products compared to the elderly people. The plausible explanation for this unexpected observation of the youth being more likely to be dependent on forest resources than the elderly could be attributed to the following reasons in the study area. The forest reserve where households undertake their harvesting activities is contiguous with Chobe National Park, which is home to the 'big five' animals. These animals especially elephants roam freely within the reserve. As such, this phenomenon may instil fear among some locals in their endeavour to undertake forest extraction activities. Therefore, the elderly people may be placed at risk compared to young people when it comes to harvesting activities.

Also, the perceived energetic nature of the young people propels them to indulge in forest extraction activities which are often labour intensive and require physical strength, as corroborated by other studies elsewhere (Fonta and Ayuk 2013; Adam and EL Tayeb 2014; Thondhlana and Muchapondwa 2014). In the light of the exhausting nature of forest extraction activities, the youth are advantaged in traversing longer distances going into the forest for harvesting forest products. On a similar note, the youth constituted a majority in Chobe district, accounting to about more than half $(55.6 \%$, $N=23,347$ ) of the entire population in the district (Statistics Botswana 2011a). The high unemployment rate coupled with deep poverty $(20 \%)$ and other social shocks in Chobe district necessitate young people to be heavily reliant on the natural resources endowed in their environment, such as forest resources. Moreover, young people are highly reliant on forest resources since they may have multiple uses of forest products compared to the elderly (Lepetu et al. 2009). For example, forest products collected for subsistence consumption may be added value and/or sold at the nearby town of Kasane.

Although the observed inverse relationship between age and forest dependency in this study deviate from the norm, the finding concurs with a small but growing body of empirical evidence demonstrating a shift in collection and utilisation of forest resources from being an activity predominantly undertaken by the elderly people to a more broader one encompassing people across various age brackets (Adam and EL Tayeb 2014; Mujawamariya and Karimov 2014; Htun et al. 2017; Ofoegbu et al. 2017; Suleiman et al. 2017), with young people posed to exhibit greater dependency on forests compared to their counterparts. The current study and the aforementioned studies argue that increases on household age have diminishing effect on forest extraction activities. Since forest extraction activities are often tedious and arduous, young people have an upper hand in collecting more forest products and sustaining the collection activities for a period of time compared to the elderly. As argued by André and Platteau (1998), younger households are being trapped into social disadvantages due to inequitable distribution of resources such as landholding and limited access to alternative economic opportunities. Hence, younger households are likely to rely more on forest resources for their livelihood sustenance.

While the study results show that the youth were likely to be more reliant on forest resources, the situation may not be too worrisome since young people are highly mobile and often migrate to towns in search for employment and other opportunities, hence lessening forest product-gathering activities. The latter is a positive aspect for forest conservation. On the other hand, studies have shown that the rural-urban migration by young people leads to a shift in roles, with old people now taking over the role of collection of forest products (Hecht et al. 2015). Hence, rural-urban migration may help relieve pressure and reliance on forest resources in cases where young people send remittances back to families to help them use alternative resources.

Thirdly, the results revealed a statistically significant and positive association between household head education level and forest dependency. The findings imply that higher educational attainment lessened reliance on forest resources. The odd ratios for the coefficients of secondary and tertiary education levels implies that households who attained secondary and tertiary education were 15 and $11 \%$ less likely to be highly reliant on forest products, respectively, compared to those with lower or no formal education. Therefore, higher levels of educational attainment reduce household's reliance on forest products in this study, a similar observation held by studies from elsewhere. This could be attributed to the notion that people with formal education have diversified livelihood options which may generate significant returns compared to forest-related activities (Masozera and Alavalapati 2004). This finding is consistent with other studies conducted locally (Lepetu et al. 2009) and 
elsewhere (Fonta and Ayuk 2013; Kabubo-Mariara 2013; Baiyegunhi et al. 2016). These studies contended that higher education offers better employment opportunities, hence diverting livelihood options away from gathering activities such as forest resource extractions.

On the other hand, the predictors' length of residency, household size, sex and employment did not reach statistical significance but showed both positive and negative relationship with forest dependency. Length of residency had a positive relationship with forest dependency. This suggests that long-term residents were more reliant on forest resources compared to short-term residents. Pattanayak et al. (2003) found length of residency to be positively influencing households' reliance on forests. In their study of Siberut Forests in Nepal, people who stayed longer in their area of settlement were highly dependent on forests compared to their counterpart, which was attributed to their familiarity with the complexities of their proximate environment.

Forest dependency and sex were negatively related. Therefore, the negative coefficient of sex implies that females were more dependent on forest resources compared to males. Generally, women are known to be highly dependent on common pool resources, including forests (Grossman 1981; Uberhuaga et al. 2012). In contrast, studies from elsewhere observed that males were more likely than females to depend more on forests and other environmental resources (Masozera and Alavalapati 2004; Thondhlana et al. 2012; Adam and EL Tayeb 2014). In these studies, men were associated with selective harvesting of forest resources, especially those which had market value such as firewood. Hence, they harvested more resources for selling compared to their counterpart. Furthermore, men were mostly using animal driven carts for gathering forest products, something which gave them the opportunity to extract more resources.

Household size had a negative relationship with forest dependency. Therefore, the likelihood of reporting higher forest dependency decreased with increase on household size. This finding is contrary to observations made by other studies elsewhere (Mamo et al. 2007; Córdova et al. 2013; Fonta and Ayuk 2013; KabuboMariara 2013; Adam and EL Tayeb 2014). These studies reported that larger families were more dependent on forest resources. Since forest activities are labour intensive, larger families have adequate manpower to allocate across gathering activities. The possible explanation for this counterintuitive finding may be attributed to differences in demographic profiles, such as household sizes between the current study and aforementioned studies. The current study's household size was generally smaller than the former studies which were composed of relatively larger household sizes, averaging six members. Placing a statistical insight on the unexpected relationship between household size and forest dependency, the mean household size had smaller standard deviation, demonstrating less spreading of the values away from the mean and each other. Therefore, the values for the variable household size were very close to the mean, hence less variability on the level of forest dependency.

Lastly, the variable employment showed negative association with forest dependency. This suggests that employed households were less dependent on forest products. Employment opportunity may offer better income generating options compared to benefits derived from the forest. Possibly, those who were employed were able to afford alternative products from the market, hence reducing reliance on forest products. Studies conducted from elsewhere found income from employment and other regular paid activities to be significantly and negatively influencing households' forest dependency (Hegde and Enters 2000; Mamo et al. 2007; Tieguhong and Nkamgnia 2012). In these studies, extraction of NTFPs was not a preferred and regular activity but only indulged in during off-employment periods as a substitute. Also, the significant association was brought about by the diversified livelihood portfolios among the studied communities compared to the current study.

\section{Conclusion}

The results suggest that Chobe enclave locals are highly dependent on forest resources for their livelihood sustenance. Therefore, forests were critical in livelihood diversification in Chobe enclave. In this study, socioeconomic factors such as place of residency, age and education level significantly influenced household forest dependency. The observed inverse relationship between age and forest dependency provides an encouraging insight. This study portrays the youth as a critical stakeholder and change agent on sustainable forest management. Therefore, young people could be capacitated with the skills and ability to initiate activities aimed at enlightening communities on the importance of forests and the need for conservation. On the other hand, people who attained higher education levels were observed to be less dependent on forest resources. Therefore, education could be used as a means of diverting household's pursuits away from gathering activities.

The study results contribute to local management and conservation strategies in the following manner: the key factors bringing about variation on forest dependency can be considered and factored into planning, designing and implementation of programs and activities for forest sustainability. On the other hand, policies should facilitate active participation of local communities in forest management and conservation. In order to foster a balance between forest dependency and biodiversity 
conservation, provision of alternative livelihood opportunities and access to higher education aimed at diversifying young people's livelihood portfolios are vital in reducing forest dependency, hence protecting forests for posterity. Lastly, this study has expanded the forest dependency literature, particularly in Southern Africa where the intricate relation between people and their immediate environment has being fairly understood.

\section{Endnotes}

${ }^{1}$ BWP 1 = USD 0.09 (2016)

\section{Abbreviations}

CFR: Chobe Forest Reserve; FDI: Forest dependency index; NTFPs: Non-timber forest products; VIF: Variance inflation factor

\section{Acknowledgements}

This study was conducted while the first author was affiliated to Okavango Research Institute, University of Botswana, during the period 2014-2016. The insightful comments made by the two anonymous reviewers are greatly acknowledged. The funding from Southern African Science Service Centre for Climate Change and Adaptive Land Management (SASSCAL) (Task 311) supported by the German Federal Ministry of Education and Research (BMBF) is greatly appreciated. The authors are grateful to the Chobe enclave locals who participated in the study survey as well as on other logistics during the entire data collection field work. Special appreciations to Denis Radebe and Frans Mothupi (Rhodes University) for editing the study map.

\section{Funding}

This work was funded by the Southern African Science Service Centre for Climate Change and Adaptive Land Management (SASSCAL) (Task 311) supported by the German Federal Ministry of Education and Research (BMBF).

\section{Authors' contributions}

HG designed the study; collected, analysed and interpreted the data and developed the manuscript. OTT and $J \mathrm{~L}$ offered constant quidance during the development of the study, and they critically reviewed the manuscript. All authors read and approved the final manuscript.

\section{Ethics approval and consent to participate}

This study was approved by the Ethics Committee of the University of Botswana (Ref: UBR/RES/RB/GRAD/207).

\section{Competing interests}

The authors declare that they have no competing interests.

\section{Publisher's Note}

Springer Nature remains neutral with regard to jurisdictional claims in published maps and institutional affiliations.

\section{Author details}

${ }^{1}$ Department of Environmental Science, Rhodes University, P.O. Box 94, Grahamstown, South Africa. ${ }^{2}$ Okavango Research Institute, University of Botswana, Private Bag 285, Maun, Botswana. ${ }^{3}$ Department of Crop Science and Production, Botswana University of Agriculture and Natural Resources, Private Bag 0027, Gaborone, Botswana.

Received: 15 August 2017 Accepted: 17 October 2017

Published online: 13 November 2017

\section{References}

Adam YO, EL Tayeb MA (2014) Forest dependency and its effect on conservation in Sudan: a case of Sarf-Saaid Reserved Forest in Gadarif State. Agriculture and Forestry 60(3):107-121
André C, Platteau JP (1998) Land relations under unbearable stress: Rwanda caught in the Malthusian trap. Journal of Economic Behaviour and Organization 34(1):1-47

Appiah M, Blay D, Damnyag L, Dwomoh FK, Pappinen A, Luukkanen O (2009) Dependence on forest resources and tropical deforestation in Ghana. Environment, Development and Sustainability 11:471-487.

Babbie ER (2016) The practice of social research, 14th edn. Cengage Learning, Boston Babulo B, Muys B, Nega F, Tollens E, Nyssen J, Deckers J, Mathijs E (2008) Household livelihood strategies and forest dependence in the highlands of Tigray, Northern Ethiopia. Agric Syst 98(2):147-155

Bahuguna VK (2000) Forests in the economy of the rural poor: an estimation of the dependency level. AMBIO: A Journal of the Human Environment 29(3):126-129

Baiyegunhi LS, Oppong BB, Senyolo MG (2016) Socio-economic factors influencing mopane worm (Imbrasia belina) harvesting in Limpopo Province, South Africa. J For Res 27(2):443-452

Beckley TM (1998) The nestedness of forest dependence: a conceptual framework and empirical exploration. Soc Nat Resour 11(2):101-120

Bhavannarayana C, Saritha V, Usha P, Rao BP (2012) Dependency and usage pattern of forest-dwellers on non-timber forest products. Erudite Journal of Ecology and Environment 1(1):1-5

Bwalya SM (2013) Household dependence on forest income in rural Zambia. Zambia Social Journal 2(1):67-86

Coomes OT, Barham BL, Takasaki Y (2004) Targeting conservation-development initiatives in tropical forests: insights from analyses of rain forest use and economic reliance among Amazonian peasants. Ecol Econ 51(1):47-64

Córdova JPP, Wunder S, Smith-Hall C, Börner J (2013) Rural income and forest reliance in highland Guatemala. Environ Manag 51(5):1034-1043

Dagm F, Wubalem T, Abdella G (2016) Economic contribution to local livelihoods and households dependency on dry land forest products in Hammer District, Southeastern Ethiopia. International Journal of Forestry Research 1-11

Fonta WM, Ayuk ET (2013) Measuring the role of forest income in mitigating poverty and inequality: evidence from south-eastern Nigeria. Forests, Trees and Livelihoods 22(2):86-105

Garekae H (2016) Forest dependency and its implication on attitudes for conservation, Chobe enclave, Botswana. MPhil Thesis, Okavango Research Institute, University of Botswana. Retrieved from http://medupe.ub.bw/ articles/1696203.11433/1.PDF

Godoy R, O'Neill K, Groff S, Kostishack P, Cubas A, Demmer J, McSweeney K, Overman J, Wilkie D, Brokaw N, Martinez M (1997) Household determinants of deforestation by Amerindians in Honduras. World Dev 25(6):977-987

Grossman L (1981) The cultural ecology of economic development. Ann Assoc Am Geogr 71(2):220-236

Gunatilake H (1998) The role of rural development in protecting tropical rainforests: evidence from Sri Lanka. J Environ Manag 53(3):273-292

Hecht S, Yang AL, Basnett BS, Padoch C, Peluso NL (2015) People in motion, forests in transition: trends in migration, urbanization, and remittances and their effects on tropical forests (no. 142). CIFOR, Bogor

Hegde R, Enters T (2000) Forest products and household economy: a case study from Mudumalai Wildlife Sanctuary, Southern India. Environ Conserv 27(3):250-259

Hosmer D, Lemeshow S, Sturdivant R (2013) Applied logistic regression, 3rd edn. Wiley, New York

Htun TT. Wen Y, Ko Ko AC (2017) Assessment of forest resources dependency for local livelihood around protected areas: a case study in Popa Mountain Park, Central Myanmar. International Journal of Sciences 6(1):34-43

Jain P, Sajjad H (2015) Household dependency on forest resources in the Sariska Tiger Reserve (STR), India: implications for management. J Sustain For 35(1):60-74

Kabubo-Mariara J (2013) Forest-poverty nexus: exploring the contribution of forests to rural livelihoods in Kenya. Nat Res Forum 37(3):177-188

Kalaba FK, Quinn CH, Dougill AJ (2013) Contribution of forest provisioning ecosystem services to rural livelihoods in the Miombo woodlands of Zambia. Population and Environment 35(2):159-182.

Lepetu J, Alavalapati J, Nair PK (2009) Forest dependency and its implication for protected areas management: a case study from Kasane Forest Reserve, Botswana. International Journal of Environmental Research 3(4):525-536

Mamo G, Sjaastad E, Vedeld P (2007) Economic dependence on forest resources: a case from Dendi District, Ethiopia. Forest Policy Econ 9(8):916-927

Masozera MK, Alavalapati JRR (2004) Forest dependency and its implications for protected areas management: a case study from the Nyungwe Forest Reserve, Rwanda. Scand J For Res 19(4):85-92 
McElwee PD (2010) Resource use among rural agricultural households near protected areas in Vietnam: the social costs of conservation and implications for enforcement. Environ Manag 45(1):113-131

Mujawamariya G, Karimov AA (2014) Importance of socio-economic factors in the collection of NTFPs: the case of gum Arabic in Kenya. Forest Policy Econ 42:24-29

Mukul SA, Rashid AZMM, Uddin MB, Khan NA (2016) Role of non-timber forest products in sustaining forest-based livelihoods and rural households' resilience capacity in and around protected area: a Bangladesh study. J Environ Plan Manag 59(4):628-642

Obua J, Banana AY, Turyahabwe N (1998) Attitudes of local communities towards forest management practices in Uganda : the case of Budongo Forest Reserve. Commonwealth Forestry Review 77(2):113-118

Ofoegbu C, Chirwa PW, Francis J, Babalola FD (2017) Socio-economic factors influencing household dependence on forests and its implication for forestbased climate change interventions. Southern Forests: A Journal of Forest Science 79(2):109-116

Panta M, Kim K, Lee C (2009) Households' characteristics, forest resources dependency and forest availability in central Terai of Nepal. Journal of Korean Forest Society 98(5):548-557

Pattanayak SK, Sills EO, Mehta AD, Kramer RA (2003) Local uses of parks: uncovering patterns of household production from forests of Siberut, Indonesia. Conserv Soc 1(2):209-222

Shackleton CM, Shackleton SE, Buiten E, Bird N (2007) The importance of dry woodlands and forests in rural livelihoods and poverty alleviation in South Africa. Forest Policy Econ 9(5):558-577

Statistics Botswana (2011a) Chobe sub-district population and housing census 2011: selected indicators for villages and localities. Statistics Botswana, Gaborone

Statistics Botswana (2011b) Population of town, villages and associated localities. Statistics Botswana, Gaborone

Statistics Botswana (2015b) Mapping poverty in Botswana 2010. Statistics Botswana, Gaborone

Suleiman MS, Wasonga VO, Mbau JS, Suleiman A, Elhadi YA (2017) Non-timber forest products and their contribution to households income around Falgore Game Reserve in Kano, Nigeria. Ecol Process 6(23):1-14

Thondhlana G, Muchapondwa E (2014) Dependence on environmental resources and implications for household welfare: evidence from the Kalahari drylands, South Africa. Ecol Econ 108:59-67

Thondhlana G, Vedeld P, Shackleton S (2012) Natural resource use, income and dependence among San and Mier communities bordering Kgalagadi Transfrontier Park, southern Kalahari, South Africa. Int J Sust Dev World 19(5):460-470

Tieguhong JC, Nkamgnia EM (2012) Household dependence on forests around Lobeke National Park, Cameroon. Int For Rev 14(2):196-212

Uberhuaga P, Smith-Hall C, Helles F (2012) Forest income and dependency in lowland Bolivia. Environ Dev Sustain 14(1):3-23

Vedeld P, Angelsen A, Bojö J, Sjaastad E, Berg KG (2007) Forest environmental incomes and the rural poor. Forest Policy Econ 9(7):869-879

World Bank (2002) A revised forest strategy for the World Bank Group. The World Bank, Washington

\section{Submit your manuscript to a SpringerOpen ${ }^{\circ}$ journal and benefit from:}

- Convenient online submission

- Rigorous peer review

- Open access: articles freely available online

- High visibility within the field

- Retaining the copyright to your article 